\title{
The institutional rationale of central banking reconsidered
}

\author{
Pablo Paniagua ${ }^{1}$
}

(C) The Author(s) 2016. This article is published with open access at Springerlink.com

\begin{abstract}
Based on Goodhart's (1988) The Evolution of Central Banks, I examine both the theoretical arguments and the historical evidence that could sustain the case for the natural emergence of central banks. I criticize Goodhart's theoretical claim that central banks evolve naturally, by showing that they are far from being uniquely capable of supplying essential banking services. I review historical evidence showing that Goodhart's historical generalizations are inconsistent with the developments of the vast majority of central banks. History also shows that crucial banking services have tended to be successfully provided by other means, except when governments prevented their development. Finally, I consider whether central banks, if not essential, are at least preferable to alternative arrangements.
\end{abstract}

Keywords Central banking · Clearinghouse - Clubs · Monetary institutions · Self-governance

JEL Classification E580 $\cdot \mathrm{H} 1 \cdot \mathrm{H} 4 \cdot \mathrm{K} 2$

\section{Introduction}

Recent experiences with business cycles have led some economists to put central banking arrangements under institutional scrutiny (Boettke and Smith 2014; Hetzel 2012). These concerns come largely from the Great Recession and the negative role that central banks might have played in it (Hetzel 2012). Nevertheless, despite these post-crisis apprehensions, most academics and policy makers have remarkably

Pablo Paniagua

pablo.paniagua_prieto@kcl.ac.uk

1 King's College London, London, UK 
continued to view central banking as a relatively efficient and adequate institutional arrangement (Goodhart 2010).

Given these institutional apprehensions, I focus on a complementary question related to the institutional resilience and critical assessment of central banks. Whereas economists have largely focused on specific policy errors, or looked to improve central banks' decision making processes (Hetzel 2012), I ask an unaddressed yet more fundamental question: Are central banks inherently necessary in the first place? And furthermore, are they necessarily the result of the banking system's natural institutional evolution ${ }^{1}$ The post-crisis literature lacks a specific articulation of institutional arguments that could largely justify the necessity and evolution of a non-profit-seeking, government-managed institution to oversee banking stability and regulation. The recent post-crisis arguments for expanding central banks' supervision and macroprudential regulatory control (Goodhart 2010), implicitly rely on a lack of profound scrutiny concerning (a) central banks' genuine institutional necessity in the banking system, as well as (b) the actual historical evolution of their roles and how they developed according to political forces outside the needs of the banking systems in order to function properly.

Given these shortcomings in the literature, coupled with a lack of critical evaluation of current monetary systems, this paper seeks to examine and evaluate crucial institutional and historical arguments concerning central banking's evolution and institutional necessity. With the establishment and consolidation of central banks throughout the world, their institutional strength and fundamental necessity are often taken for granted. Believing in central banks' comparative superiority as an institutional solution to regulation and macroeconomic instability risks becoming dogma. By disregarding the wider historical evidence, it is also possible to overlook the fundamental political and sovereignty reasons why central banks were established and how they developed from fiscal forces (Marcussen 2005). Historical evidence casts severe doubts regarding their natural evolution and unique institutional position to promote stability; this questions their inevitability and underlying justification as optimal institutional responses to banking failures and crises (Selgin 1988). To examine crucial institutional arguments and historical evidence that might sustain the case for the natural emergence of central banks, I draw on Goodhart's The Evolution of Central Banks.

To fully address Goodhart's (1988) central banking evolutionary claims, I examine both the history and theory justifying the establishment and evolution of central banks. I do this in order to see whether the arguments in favor of their

\footnotetext{
${ }^{1}$ I define central banks as systems in which a single banking entity has either a complete or residuary monopoly over the service of issuing notes. In contrast, the complete absence of governmental restrictions on entry and competition in note issuance and banking leads to a free banking system. It is sensible to distinguish between the modern conception of central banking and their broader roles with proto-central banks that previously had banking privileges without any clear stability role (Dowd 1993, Chapter 11; Meltzer 2009). Proto-central banks reluctantly adopted clearer stability roles slowly and only in the late nineteenth century; this occurred following intense public debate for their need to acknowledge "lender of last resort" responsibilities as palliatives to the already existent problem of the monopoly over issuing notes (Selgin 1988, pp. 119-122; Thornton 1978/1802). Hence theories that treat monopoly privileges as an evolutionary consequence of supervisory and regulatory responsibilities distort actual historical sequences.
} 
emergence and rationality can withstand a critical evaluation, as well as if the historical record disproves or supports his evolutionary arguments. I scrutinize the theoretical and historical claims that could justify their institutional inevitability, inherent necessity and institutional comparative advantages over alternative institutional possibilities.

Regarding other potential arrangements, there have been small advances in bringing together the banking literature with the institutional and self-governance literature (Hardy 2006; Yue and Ingram 2012). I aim to contribute to these advances by providing a political economy account of banking institutional evolution and by bridging comparative institutional analysis with the theory of clubs and selfgovernance. The latter illuminates the comparative advantages and institutional resilience of different private arrangements such as 'clubs' that could provide successfully crucial banking services. There is an important gap in the literature since a political economy and institutional analysis has not been applied thoroughly to evaluate the rationality and evolution of central banks and their institutional resilience. By applying such a critical political economy analysis, this paper also shows the potential resilience of alternative self-governing banking arrangements over central banks. Hence it contributes to the literature by suggesting novel theoretical ways forward in seriously considering polycentricity and other institutional possibilities to effectively manage banking stability and financial regulation.

The purpose of this paper is twofold. First, it scrutinizes Goodhart's rationale for the emergence of central banks as the natural and intrinsic outcome of banking systems' inherent economies of reserve holding, and secondly it pursues a comparative institutional analysis between clearinghouses and central banking. Since Goodhart's arguments rest on both history and theory, it is imperative to address them separately. The historical evidence shows that Goodhart's evolutionary generalizations are inconsistent with the historical development of the vast majority of central banks. History shows that central banks were established not due to a natural banking evolution, but due to fiscal forces, international political pressure and government sovereignty (Marcussen 2005). Similarly, theoretical considerations show that Goodhart's rationale for the natural emergence of central banks is misplaced. In fact, theoretical arguments sustain a wider spectrum of institutional possibilities perfectly capable of supplying crucial banking services. Borrowing from Buchanan's contributions to constitutional political economy and the "theory of clubs" (Buchanan 1964, 1965, 2008), I examine the institutional evolution of banking systems to see whether they justify the 'natural' centralization of reserves in a single bank or justify a wider set of alternative institutional responses. Contrary to Goodhart, theory suggests that the institutional evolution of banking does not necessarily lead to a bankers' bank.

The analysis of the historical evidence and the theoretical arguments of Goodhart's thesis are necessary to fully examine his rationale for central banks. Taken together, they show that his evolutionary account is incorrect. Not simply because there are other institutional possibilities that could emerge to provide banking services, but also because central banks in reality have not been the product of evolutionary tendencies to supply banking services. History indicates that crucial banking services have tended to be successfully supplied by other self-governing 
arrangements. The exception is when governments and regulations have prevented these other arrangements to develop.

The purpose of the second part of this paper is to undertake a comparative institutional analysis between competitive clearinghouses with central banking. This is to see whether central banks, if not essential, can still be justified when compared with possible alternatives. ${ }^{2}$ Central banks may not be the natural result of the institutional evolution of banking but comparatively could still be superior to other institutional alternatives. For this analysis I draw on self-governance and club theory to see whether alternative forms of clearinghouse "club" arrangements might prove more resilient institutionally than central banks. ${ }^{3}$

The following section examines the core "micro functions" proposed by Goodhart (1988) and relevant historical developments that challenge his historical generalizations. Sections 3 and 4 then focus on theoretical aspects of the institutional development and diversity of banking arrangements, and an institutional comparative analysis between central banking and clearinghouses.

\section{A historical account of centralization of reserves}

Despite economists more frequently talking about the monetary policy aspects of central banks, it is often noted that they could be justifiable or even necessary since they could generate additional confidence in the banking system in times of crisis. Central banks could accomplish this by providing liquidity, leadership, regulation, and surveillance of the banking members (Goodhart 1988, pp. 44-47). Goodhart acknowledges that while the monetary policy roles of central banks have changed drastically through time, there are still other functions that have remained unaltered. These roles include ensuring financial stability, supervising banks, and mitigating banking crises through regulation and liquidity. Goodhart defines these roles as "micro functions" of central banking. ${ }^{4} \mathrm{He}$ sustains that "the monetary (macro) functions of Central Banks were largely grafted onto the supervisory functions, and not the reverse ... [this] implies that the central core and rationale for the existence and operation of a Central Bank is not necessarily to be found in its macro-economic role" (Goodhart 1988, p. 7). Goodhart considers that the core justification of central banking rests on these micro (regulatory) functions, consisting of providing a central and efficient source of reserves and liquidity to banks and therefore proper insurance and constant monitoring and regulation of them. He ultimately establishes that these micro functions justify the institutional evolution of central banks since these functions arise naturally as the consequence of a gradual centralization of reserves into the control of a single entity in the whole banking system (Goodhart 1988, chapter 1). The tendency

\footnotetext{
${ }^{2}$ Clearinghouses are voluntary associations with the main functions of clearing notes, drafts, checks, and bills of exchange, as well as regulating the club members (Goodhart 1988, chapter 3). These services are only accessible to club members. See also Timberlake (1984) and Trivoli (1979).

3 For contributions to club theory and institutional self-governance, see Buchanan (1965), Ostrom (2000, 2010) and Tiebout (1956).

4 I use the "micro functions" concept throughout the rest of this paper to refer to a bundle of services related to financial and banking supervision, regulation, and "lending of last resort."
} 
for such a concentration of reserves puts the entity that receives the banks' reserves in the unintended (and fragile) position of being a for-profit "bankers' bank;" in addition to competing with other banks, a bankers' bank must also serve as the ultimate source of liquidity and support for other banking competitors. Thereafter, in order to perform that 'liquidity support' role, it also must assume complementary supervisory, monitoring, and regulatory functions (Goodhart 1988, pp. 7-8).

This natural process of concentrating reserves into a single competitive bank is the foundation of Goodhart's justification for a noncompetitive central bank and hence its rationale (Goodhart 1988, pp. 5, 34, 37, 73; Selgin 1993). Subsequently, Goodhart seeks to further support his thesis by utilizing historical grounds; he analyzes mainly two historical episodes by which he subsequently generalizes his institutional conclusions. He reviews the evolution of the Bank of England and the Suffolk experience, episodes which I review in Sects. 2.2 and 2.3, respectively. Goodhart's core assumption concerning how the institutional process of concentration of reserves causes the micro functions to arise rests on his claim that the natural competitive banking forces inevitably leads to the concentration of "bank balances among a few, central, wellestablished commercial banks, in some cases one or two banks" (Goodhart 1988, p. 34). This allows those special bankers' banks to become the systems' main holders of reserves and the ultimate source of liquidity to the rest of the system. From their unique role as the ultimate liquidity providers and holders of reserves, they necessarily have to develop supervisory and regulatory functions over other banks. Consequently, the natural concentration of reserves of the entire system into a single for-profit bank worsens bank runs and liquidity issues. This is due to the contradiction of those banking institutions: being the bankers' bank while simultaneously also being a for-profit competitive entity. The contradiction and the strong for-profit motive, leads bankers' banks to mishandle crises and act inconsistently with public interest (Bagehot 1873). Such banking behavior stems from trying to profit and leverage their preferred position to overload other competitive banks with unnecessary regulation or even potentially use discretion to make them fail in case of liquidity constraints (Bagehot 1873; Goodhart 1988, pp. 38-39). The institutional progression then has to conclude with the "natural" creation of a central bank to establish a nonprofit structure. The nonprofit nature of the central bank enables it to alleviate its fear of draining reserves without losing profitability (since it is not part of its public functions) and therefore able to fully address the public interest (the core micro function) with strong leadership (Goodhart 1988, pp. 45-46). In sum, Goodhart's rationale for central banks rests on two elements: first, their natural institutional role as a major (or the only) accumulator of reserves. Second, their ability to monitor, regulate, and provide liquidity (the micro functions) while escaping any conflicts of interest (Goodhart 1988, pp. 37-39, 53-55). Concerning the following historical evidence that could support or refute the aforementioned thesis outlined, the fundamental question I address is whether or not centralized institutions have indeed evolved throughout history as Goodhart suggests.

\subsection{The diffusion of central banks}

Goodhart's (1988) historical arguments rest mainly on his interpretation of the development of the Bank of England and the Suffolk system (cases which I later 
review). However, it is never prudent to draw generalized institutional conclusions based on such a narrow set of historical experiences. As such, Goodhart's historical conclusions supported by merely two cases seems to be hasty and unsubstantiated. After all, the evolution and the history of the establishment of central banks is a matter of a much wider historical record (Singleton 2011). There is considerable historical evidence that challenges Goodhart's historical proposition, supporting instead broader fiscal and political origins interpretation.

Concerning the earlier proto-central banks (see footnote 1) established in Europe before the twentieth century, Smith (1990/1936) provides historical evidence that proto-central banks around Europe were established under governments' financial and fiscal considerations. Proto-central banks were originated through the necessity of sovereigns to have access to better terms for their long-term financing efforts, to raise money for their governments, and to have expedient access to credit on demand (Broz 1998, pp. 234-236). They were specifically established as a type of bankers for the government with the objectives to become exclusive managers and fiscal agents to governments' debt and as institutional solutions to improve their damaged creditworthiness (Broz 1998). Their establishment consisted of politicaleconomic relationships in which those banks benefited from unique legal and banking privileges; their role also involved financial activities to improve states' ability to borrow in order to further their international objectives, specifically those related with military competition and international colonization processes (Calomiris and Haber 2014).

According to Broz (1998) and Glasner (1989, chapter 2), national defense and war uncertainty largely contributed to the establishment of earlier proto-central banks and to the ever increased control of monarchs over coinage. Proto-central banks were conceived as state-led institutional answers to improve governments' abilities to borrow and to quickly mobilize resources during wartime (Broz 1998, pp. 236-239; Calomiris and Haber 2014). Unpredictable war financing distress led sovereigns to gradually expand their control over both coinage and the banking system as expedient and cost-effective ways to obtain revenue during unforeseen emergencies (Glasner 1989, pp. 29-32).

Selgin and White (1999) also show that the organization of money production evolves institutionally as an unintended product of the gradual accumulation of tax and revenue enhancing innovations made by sovereigns attempting to maximize government revenue. Governments in fact have not consciously designed monetary arrangements from scratch in order to attain fiscal ends. Nevertheless, their circumstantial fiscal needs and the "gradual accretion of revenue-enhancing changes" in the banking system through time have severely and unintendedly shaped them (Selgin and White 1999, p. 164). Fiscal motivations to provide themselves with seigniorage and recurrent favorable terms in credit financing have led governments to control the supply of currency. Thus "revenue-seeking governments have opportunistically modified private-market arrangements as these developed" (Selgin and White 1999, p. 155). Thus national security and fiscal forces, not natural reserve dynamics, have severely shaped the institutions of money and their structures toward revenue and seigniorage-enhancing institutions such as monopoly banks of issue. 
Additional historical examples that provide evidence contrary to Goodhart's "natural evolutionary" arguments concern the unusual and sudden increase in the establishment of central banks throughout the twentieth century. The total number of central banks grew exponentially from 19 in 1900 to 174 by 2000 (Marcussen 2005; Singleton 2011). Interestingly, the sudden growth over the century took place in 'waves' or successive specific periods of large increases in establishments. Their growth reflected consecutive but different patterns of international diffusion rather than an endogenous natural banking evolution (Marcussen 2005). After WWI, the majority of the newly established central banks were founded as part of successive institutional 'waves' that answered to different 'diffusion mechanisms,' frequently related to international politics and government sovereignty (Clay 1957; Sayers 1976). Thus the establishment of central banks responded to the role of ideas, nationalistic ambitions, and to international political pressure as major drivers of their international growth (Jácome 2015; Marcussen 2005). These different mechanisms of diffusion that explain the establishment of central banks are historical facts at odds with Goodhart's 'natural' historical claims.

For example, by the end of WWI, there were 25 central banks (Marcussen 2005). After the war, the active international coordinative efforts led by Montague Norman and Benjamin Strong and consolidated at the Brussels and Genoa Conferences; the number of central banks increased substantially to 40 (Clay 1957; Jácome 2015). During the 1920s, cooperation between Norman and Strong helped financial and monetary reconstruction around Europe (Einzig 1932). Norman and Strong, true believers in international post-war cooperation guided by central banks (Clay 1957), framed their 'international cooperation' program early in the 1920 League of Nations meeting. There, "with a remarkably broad consensus it was agreed to call for every country to have a central bank" (Marcussen 2005, p. 912). Due to this campaign and the international difficulties with reconstructing the gold standard, governments were convinced to establish new central banks and to join the international collaboration to build a post-war monetary order (Einzig 1932; Singleton 2011). Similar dynamics occurred in Latin America and in the 'British Dominions' during the interwar period (Jácome 2015; Sayers 1976). These international dynamics could hardly be considered a 'natural' institutional development inherent to banking. Of today's central banks, 21 were established during these inter-war political international efforts (Marcussen 2005). This suggests that central banks' international experiences throughout the twentieth century responded to diverse motives such as international politics and the role of ideas (Clay 1957; Sayers 1976). This is further supported by the unusual growth of newly established central banks during the "Post-colonial wave" in which their numbers increased by $75 \%$ in response to new sovereignty needs to project "a sign of statehood" by former colonies gaining political independence (Marcussen 2005, pp. 914-915). These diverse mechanisms for the diffusion of central banks cannot be said to respond to endogenous and natural dynamics inherent in banking. The fact that central banks were established to respond to different diffusion mechanisms is crucial historical evidence demonstrating that Goodhart's (1988) claims are inconsistent with how the vast majority of central banks actually developed. 


\subsection{The bank of England}

Goodhart's (1988) historical generalizations in his evolutionary account of central banks seems unwarranted, at least when considering the wider trends of their establishment. In addition, the same two specific cases he reviews in The Evolution of Central Banks can be used to contest his historical claims. While I grant Goodhart's argument true concerning the natural tendency toward the concentration of reserves in banking (see also Selgin 1993), it does not logically entail an almost complete concentration of reserves in one competitive bank. The tendency towards a severe and unique concentration could only be understood once fully acknowledging the market and legal-regulatory framework in which those banks make their choices and to which they adapt their institutions accordingly. Monopoly powers and legal restrictions in banking severely guides the institutional evolution from a decentralized banking system holding their own reserves toward a centralized system.

The Bank of England is a crucial historical example where this tendency exists in the context of growing banking privileges and legislation. After the establishment of the Bank in 1694, it received several special legal privileges and monopoly powers at the time of each renewal of its bank charter (Broz 1998; Smith 1990/1936). Those privileges were a monopoly on keeping government balances, a monopoly of chartered banking and an exclusive limited liability status (this last privilege lasted one and a half centuries), among others. ${ }^{5}$ Subsequently in 1708 the Bank's charter was renewed. The Act specified that "no firms of more than six partners might issue notes payable at demand or at any time $<6$ months" (Smith 1990/1936, p. 13). This effectively excluded joint stock firms from the business of issuing notes, and hence from the banking business, establishing a monopoly over joint-stock note issue (Broz 1998). This gave the Bank a monopoly of joint-stock banking prior to 1826, confining other banks to a partnership of six partners or fewer, prohibiting "jointstock banks ... from issuing notes" (Selgin 1988, p. 6). Through time, the legal restrictions and privileges changed accordingly to the bargaining powers between the government and the Bank (Broz 1998). ${ }^{6}$

More importantly - for the process of the concentration of reserves - the Bank's monopoly over London's note issuance business remained unaltered for an extensive period of time (Broz 1998; Calomiris and Haber 2014, p. 85). Regarding the dynamics of concentration of the reserves of the banks in England, the key factor was then precisely the Bank's practical, statutory monopoly of note issue in the greater London area. This compelled other banks to treat its notes, and therefore its deposit liabilities, as cash reserves, superior to gold itself. Due to the Bank's monopoly of note issue in London, other London banks had to rely on their reserves of Bank notes to supply depositors' currency requirements (Selgin 1988, p. 119). London banks were not allowed to issue their own notes in order to meet the

\footnotetext{
5 For a review of the Bank's evolution of its privileges and charters, see Broz (1998).

6 The evolution of the Bank responded to England's war efforts rather than natural banking developments. The government reacted to spikes in military spending by renegotiating charter renewals. Since negotiations were within the context of war pressures, it tended to secure increasing monopoly powers to the Bank, leading to an unnatural central position in England (Broz 1998).
} 
public's changes in their relative demand for currency. This compelled them to rely on Bank of England notes to meet increases in the demand for currency, leading Bank notes to unintendedly occupy a privileged position in banks' portfolios. Thus "the extraordinary demand for currency in London could only result in an extraordinary demand for Bank of England notes" (Selgin 1988, p. 120; see also Thornton 1978/1802). The Bank's monopolist note-issuing position compelled other banks to use Bank of England notes as their cash reserves and to keep balances and gold reserves with it, which caused the English system's reserves to gradually concentrate (Broz 1998).

The incentives to concentrate reserves in the Bank of England were further exacerbated when English banks had the certainty (given by law or precedents) that the special bank holding their reserves will under any circumstances be able to give out those reserves in a medium that will be accepted by the public at all times. This is exactly the case with a bankers' bank whose notes are (or become) legal tender or that has suspended payment of its notes (Smith 1990/1936). ${ }^{7}$ Banks will further possess the incentives to choose to concentrate their reserves in a competitor bankers' bank since it is to their economic benefit to do so, given the Bank of England's unique monopolist and political status and given the exclusive status of its notes (Bagehot 1873; Broz 1998). With a centralized institution as the sole supplier of currency in London that is able to secure and always able to provide the reserve medium-since it has the monopoly powers to do so-it is perfectly natural (given banks' limitations to issue notes) for a banking system to have cash reserves and gold reserves concentrated in that single entity (Dowd 1993). This however, follows from the prior existence of the monopoly of note issue, the legal powers granted by the government and the subsequent legal precedents of the suspension of payments of the Bank notes, which further altered the institutional dynamics of the concentration of reserves.

The concentration of reserves was therefore guided mainly by the Bank's monopoly of note issue and later reinforced by legal precedents that ensured that the Bank and its notes were supported politically and by law. These privileges and legislations guaranteed that its notes could be accepted in the country, changing the incentives of the competitor banks to seek Bank notes to back their own. The suspension period between 1797 and 1811 further contributed to enhancing the status of the Bank's notes (Dowd 1993). Additionally, in 1833 the government declared Bank of England notes legal tender for all payments, with severe additional institutional implications, since "country banks began to look on them [Bank notes] as backing their own note issues" (Smith 1990/1936, p. 16). Essentially, the legal tender status of Bank of England notes had additional institutional implications into the process of the concentration of reserves; but it was mainly as reinforcing the "centripetal forces" and tendencies already present due to the initial unusual situation of the Bank's monopoly of note issue. By the time the legal tender status of Bank notes was established, the treatment of Bank of England balances and notes as

\footnotetext{
7 In 1797 an act of Parliament allowed the suspension of payment of Bank notes, legalizing the capacity of bankruptcy of the Bank. This created a crucial legal precedent in which competitive banks started to expect the government to act in this way, giving a unique special status to Bank notes. This was further reinforced when the government declared them explicit legal tender (Dowd 1993).
} 
cash reserves was already established as a result of the Bank's monopoly of London circulation (Selgin 1988, p. 6). Nevertheless, the government's credible commitment of ensuring that Bank notes would always be accepted as legal payments due to their inconvertibility and legal tender status further assured other banks of the superior status of Bank of England notes. Thus these unique legal precedents and the Bank's monopoly of note issue generated a sort of "Gresham's law" effect in the English system in which individual banks concentrated gold and cash reserves and started using Bank of England notes as their reserves instead (Dowd 1993).

This unusual reserves concentration process stands opposite to what would happen under an institutional arrangement in which no bank is given monopoly status over note issuance and its notes made quasi legal tender (Selgin 1988). As Bagehot (1873) noticed, this concentration of reserves is not the natural outcome of all banking systems, but rather the logical conclusion of a gradual accumulation of special powers given to the Bank of England (see also Smith 1990/1936, chapter 10). The monopoly powers and legal precedents radically shaped the framework and incentives that other banks faced, compelling them to prefer Bank notes as their main reserves rather than seeking other institutional alternatives to guide the reserves' "centripetal forces." Consequently, Goodhart's first historical example does not actually support a generalized natural institutional evolution of central banks.

\subsection{The Suffolk experience}

Goodhart uses the Suffolk Bank experience as his second historical example to show how the evolutionary tendencies of banking inevitably lead to the concentration of reserves in a single bank, as well as how this reserves concentration process can occur without the unique bank necessarily having special privileges. He uses the Suffolk case to sustain the claim that a quasi-central bank can naturally emerge from the competitive forces and the voluntary association of competing members and to justify as necessary the institutional transition toward and rationale for a central bank. ${ }^{8}$ Bankers' banks similar to the Suffolk experience (Goodhart 1988, chapter 3) are sometimes considered to behave like quasi-central banks, different from voluntary clearinghouses since the bank providing the service is still a competitive commercial bank, not a club. This for-profit banking structure raises a clear conflict of interest and creates perverse incentives, leading bankers' banks systems to become dysfunctional due to their incapacity to impartially deal with a 'public' function while being a for-profit competitive entity (Bagehot 1873; Goodhart 1988, pp. 38-43). Nevertheless, defining a bankers' bank like the Suffolk as a quasi-central bank is actually misleading. Unlike central banks, the Suffolk system did not possess a monopoly of note issue and rival banks did not use its liabilities as high-powered money (Lake 1947, p. 191).

It is critical to emphasize the market and legal context, and the institutional framework within which the Suffolk bankers' bank was allowed to emerge. When

\footnotetext{
${ }^{8}$ For a review of the Suffolk Bank, see Lake (1947) and Trivoli (1979). Also see the stability properties of the Suffolk in Calomiris and Kahn (1996).
} 
the Suffolk system was established in Boston in 1819, the United States had a banking system of decentralization without freedom, due in large part to special legal limitations in chartering and restrictions for deposit banking and note issuance circumscribed under specific state laws (Dowd 1993). Of crucial importance in this case was the prohibition of branch banking, which "slowed the evolution of an efficient system of note exchange and clearing, thwarting normal competitive checks against overissue" (Selgin 1988, p. 14). The result of prohibiting branch banking in the U.S. led to the institutional formation of a unit-banking system that was highly fragmented, fragile and dispersed (Calomiris and Kahn 1996). This fragmented banking context hindered the development of both an expedient system of note exchange and strong institutional checks against banks' overissue. This created the conditions by which notes needed to travel large distances to be redeemed by other banks, creating serious time-lag problems for clearing and incentives to overissue (Lake 1947; Smith 1990/1936). The time lags between note issuance and redemption created the economic incentives for country banks to issue larger volumes of notes as long as the chances of their being presented for redemption were small. This was exacerbated for geographical reasons and by states' restrictions on branch banking, which incentivized country banks to issue large amounts of notes by placing themselves in remote areas away from large city centers. This allowed, for example, country banks in Massachusetts to attempt to free ride on the clearing and circulation of their own notes by moving as far away as possible from Boston, attempting to overissue notes in the city (Lake 1947; Smith 1990/1936, p. 49). Thus country banks in Massachusetts increased their volume of notes in circulation in Boston because of that institutional lag of redemption. Branch-banking restrictions made it particularly difficult for Boston banks to redeem out-of-town ("country") banks' notes expediently and to counter their circulation in Boston (Dowd 1994).

The Suffolk system was therefore the institutional reaction to deal with the branching prohibition and the geographic and legal context in order to form a 'collective response' by city banks against country banks' notes circulation in Boston, as well as their potential risk of overissue (Calomiris and Kahn 1996). The formation of the Suffolk was meant to deal with those large volumes of country banks' notes that remained in circulation in Boston with "the intended effect of curtailing circulation of the country banks" (Smith 1990/1936, p. 49). Henceforth the Suffolk was actually not the result of the banking system's inherent natural forces to concentrate itself (Calomiris and Kahn 1996). The Suffolk could actually be seen as an endogenous response-given branching restrictions - to the inefficient note exchange and clearing system which was unable to frequently return notes to its issuers, and incapable of maintaining checks against overissue. Problems largely originated by prohibitions of branch banking in the first place (Selgin 1988, p. 14).

Additionally, states' charter regulations and limitations (although Massachusetts had one of the least strict ones) raised severe barriers to entry and costs to establish new competitors 'bankers' clubs' (Lake 1947). Other potential groups of banks were constrained from forming their own competitive clearinghouses without strict hierarchical arrangements, severely weakening clearinghouse competition. Stiffer branch-banking restrictions and states' regulations to charter led banks to rely on 
bankers' bank arrangements with much broader and authoritative regulatory powers over their members. Thus the Suffolk operated with overly constraining rules, shifting operating costs and risk to its members, while also giving them a 'highhanded attitude' (Calomiris and Kahn 1996; Dowd 1994, p. 295). Suffolk members' discontent incentivized them to try to establish another competitive banking club. However, states' charter restrictions and political opposition by the legislature made the entry and establishment of such competitive clubs excessively difficult (Lake 1947, pp. 193-196).

Nevertheless, after several attempts to obtain a charter, the rival Bank of Mutual Redemption (BMR) was established in 1855, which offered clearinghouse and banking services on much better terms and was less hierarchical than the Suffolk system (Calomiris and Kahn 1996). The crucial institutional difference between the BMR and the Suffolk was that the former was an actual voluntary bankers' club arrangement, which was owned by its bank customers rather than a commercial bank competitor, or a bankers' bank such as the Suffolk (Lake 1947, p. 196). Hence the BMR had the structure of a competitive bankers' club, which avoided the conflicts of interest and over regulation of its members (Dowd 1994, p. 296). The fact that Suffolk clients defected for the BMR, and that the Suffolk eventually abandoned the market, indicates banks' actual preferences for much more limited and less hierarchical bundle of services (Dowd 1994, p 296; Lake 1947). More importantly, the fact that banks opted out of a bankers' bank for an actual bankers' club arrangement is crucial historical evidence that further disputes Goodhart's historical claims. This example shows that competitive clearinghouses were in fact not only successful and feasible institutional solutions (whenever allowed) but also preferable to a bankers' bank to provide the bundle of services that banks actually desired.

Hence it is not at all evident that without restrictions on branch banking, charter procedures, and legal restrictions against entry, the dynamics of banking and reserves would have naturally tended to form a sort of Suffolk system. What this experience actually demonstrates is that the natural tendencies to centralize reserves were-in this specific case-guided by the regulatory framework that severely restricted chartering, competition and branching. Thus the "centripetal forces" of reserves concentration, guided by branch-banking restrictions, temporarily led to a for-profit bank to act as a bankers' bank until club competition could arise. This case does not justify Goodhart's historical generalization claiming that the natural tendencies of reserves will inevitably lead to a bankers' bank to transition toward a nonprofit central bank.

\subsection{Voluntary clearinghouses and branch banking}

Additional historical evidence also shows that institutional frameworks that did not set precedents of rigid banking legislations and restrictions over branch banking experienced entirely different institutional manifestations of the dynamics of reserves. Most of them have actually led to institutional arrangements predominantly decentralized and self-governing in order to provide crucial banking services. Indeed, there are several historical episodes documented of relatively successful 
banking institutional arrangements, largely based on branch banking, bilateral clearing arrangements and voluntary clearinghouses whenever freedom of competition and branching existed (Dowd 1992; Schuler 1992).

For example, during the "free banking" or antebellum period in the United States, different regions established private clearinghouses that helped their banking systems to clear banks' rival notes, check their overissue, increase 'netting economies' of interbank dues, and regulate their members (Dowd 1993, chapter 8; Timberlake 1984). ${ }^{9}$ During this period, banks started to use these institutions voluntarily not only as clearinghouses but also coordinated private lending by keeping part of their reserves as deposits with them (Dowd 1994; Timberlake 1984). This allowed clearinghouses to adopt certain functionalities, particularly the supervision and private regulation of their members, evaluating applicants' financial integrity, and the possibility of coordinating lending in case of liquidity constraints (Trivoli 1979). The crucial characteristic of clearinghouses is that they successfully provided the "micro functions" competitively. Unlike central banks, they competed without having monopoly over note issuance nor any other specific legal or banking privilege (Dowd 1994). In addition to clearinghouses, in institutional settings that largely allowed competitive branch banking to develop (as was the case in Canada and Scotland), the natural tendencies of the concentration of reserves led primarily to private branch-banking networks (Dowd 1992). Those private networks were often either accompanied by bilateral informal agreements to clear notes or voluntary associations of clearinghouses, in order to reduce the need of overall reserves (Dowd 1993; Schuler 1992). It is worth noting that the institutional possibility of bank branching is a crucial aspect of credit efficiency, economies of scale, and netting economies of interbank dues. In fact, banks largely seek to rely on branch banking and treat it not only as an alternative but as a key complement to bilateral agreements, clearinghouses and/or bankers' banks (Dowd 1994). Building a network of branches allows interbank clearing and settlements to occur at the local level, avoiding unnecessary transactions costs of doing them solely in one central location.

Branch banking is important to reap economies of scale and netting economies. In fact, under legal contexts dominated by competition among few banks and freedom of branching, the institutional evolution leaned toward wider branching networks and cheaper bilateral clearing arrangements. Thus clearinghouses or a bankers' banks become far less relevant, or even unnecessary, for banking systems to work properly (Dowd 1994; Schuler 1992). ${ }^{10}$ For example, during its freebanking period, Canada largely allowed competition and branch banking. This created the conditions for the banking system to function properly largely on the

\footnotetext{
9 Before the establishment of the Fed in 1913, the U.S. banking system was far from competitive in its branching, which could make the U.S. case somewhat misleading. The regulatory framework that prohibited branch banking across state lines led to the formation of far more centralized and autocratic clearinghouses (Dowd 1992).

${ }^{10}$ In a free banking context, the emergence of clearinghouses might not even be necessary. This holds true in cases where the cost of setting an overseer of interbank lending outweighs the benefits of going to a decentralized market. In systems with few banks, the netting economies of interbank settlement can be reaped solely through branching and bilateral agreements (Schuler 1992).
} 
basis of private branching networks and informal bilateral clearing arrangements. Banks' private branching networks can attain economies of scale comparable to other arrangements, up to a point, making more complex and costly centralized institutions less necessary (Dowd 1994; Schuler 1992). ${ }^{11}$ The Canadian experience, as well as others around the world (Dowd 1992; White 1984), are in fact private institutional solutions contrary to Goodhart's generalizations in which small, independent bank units will always seek "quasi-Central Banking functions" in a competitor (Goodhart 1988, pp. 34-38).

On the other hand, some countries such as the aforementioned U.S. case had stiffer branch-banking restrictions and far more regulation for banks' charters and operations. The institutional tendencies led instead toward establishing more complex and formal multilateral clearing arrangements, which exercised greater regulatory powers over their members (Dowd 1994, p. 298). These systems relied on stronger and more controlling clearinghouses, but not particularly by granting a privileged unique position to any competing bank. They usually formed strong 'club associations' that then developed more hierarchical banking and regulatory services (Timberlake 1984). These different levels of centralization and hierarchical institutional differences in historical cases indicates a direct institutional relationship between clearinghouses' degrees of hierarchy and regulatory powers and existent banking legal restrictions (Dowd 1994, pp. 295-297). In fact, whenever banks experienced considerable freedom to compete and branch, the institutional evolution leaned away from bankers' banks and "strong clubs," leaning instead toward a combination between branch banking, bilateral clearing agreements, and possibly some voluntary associations (Dowd 1992; White 1984).

All these different systems show an actual broader range of alternative and plausible private institutional formations in banking, as well as successful combinations of them. The evidence of successful private institutional heterogeneity in banking systems again disputes Goodhart's (1988) historical claims. Moreover, history further disputes Goodhart's evolutionary thesis by showing that crucial banking services have been successfully provided by other voluntary institutional means. This conclusion has important and broader constitutional implications. It suggests that the existence of branching restrictions, the degree of market competition, and the rule of law that governs banking interactions and defines their property rights have been crucial in shaping the evolution and the structures of banking cooperation. Therefore, the broader "constitutional framework of banking" and their rules for cooperation, have severely determined and limited how banks can plausibly appropriate scale economies and promote cooperative arrangements in order to supply the "micro functions."

\footnotetext{
11 The benefits of the convergence of reserves stems from economic efficiency. Considerations include economies of scale, risk diversification, lack of branches in a given geographical sector, and simplification of interbank payments (Dowd 1994). The economies of scale achieved through centralizing reserves mainly comes from netting economies. Banks that park reserves in a single bankers' club can achieve expedient and cost-efficient 'netting out' of interbank dues prior to settlement. Those economies could actually be reaped without any centralization of the settlement medium. However, some degree of voluntary centralization does offer benefits by largely reducing the settlement transaction costs.
} 
As suggested in this section, there will always be an institutional tendency for banks to allocate and concentrate their reserves, and to seek interbank lending arrangements whenever possible to economize resources and minimize risk (Selgin 1993). This tendency could also lead to branching networks or other private formations and institutional combinations that could provide the required services in accordance with the given context of incentives and legal precedents. The 'constitutional context' and regulatory regime under which banks function shape how the economies of reserve holding operate institutionally; they also constrain how voluntary collective action could potentially internalize banking services. ${ }^{12}$ Therefore, the intrinsic existence of Goodhart's general "centripetal forces" (which drive banks to seek economization of reserves and netting economies) should not be confused with those specific tendencies in given 'constitutional contexts.' Consequently, Goodhart's historical generalization of central banks is incorrect not only because it is inconsistent with the vast majority of their developments but also because history shows that crucial banking services have tended to be supplied by other private means-whenever the legal context permitted them-without any necessity for central banks to emerge.

\section{Institutional diversity conditioned by the legal framework}

The different institutional arrangements explored in the previous section evince different plausible evolutionary paths that the banking system might take to carry out the "micro functions" identified by Goodhart (1988). These varying institutional forms can theoretically be rendered comprehensible, with what Buchanan called "different rules, different games" (Buchanan 2008). Based on these diverse institutional formations, I argue that some sort of concentration of reserves along the banking network is a natural tendency of the competitive banking business and it is present regardless of the regime that banks face (Selgin 1993; White 1984). However, this inherent nature of banking does not mean that the tendency will inevitably lead toward a single entity that naturally transitions into a noncompetitive central bank. To do so, the legal and constitutional framework under which banks are making their choices would need to be clearly defined since these determine banks' incentives, possible economies of scale, as well as institutional possibilities for cooperation. The institutional 'equilibrium' of the concentration of reserves and the formation of clearing and branching nodes across the banking structure do not necessarily have to form a single entity, as Goodhart assumes. Following Buchanan (1964, 2008), different banking rules and restrictions can determine the different institutional 'games structures' for how banks deal with reserves and cooperate institutionally in order to provide the "micro functions." There is nothing inherent in these real reserve tendencies lending itself to a single point structure and even less so into a single competitive bank (Schuler 1992). As Buchanan (1964) suggests, the degrees of competition of the market order "come to be established as

\footnotetext{
${ }^{12}$ The 'constitutional context' refers to the specific framework of rules, or "the rules of the game" and the mechanisms for their enforcement (Brennan and Buchanan 2008 [1985]).
} 
institutions emerge to place limits on individual behavior patterns" (Buchanan 1964 , p. 29, emphasis in the original). Analogous to the market order, the banking system will form an institutional structure according to limits imposed by the 'constitutional context'. It will also obtain a degree of competition through establishing auxiliary cooperative arrangements to seek gains from cooperation and economies of scale whenever allowed. The establishment of such structures depend on the legal framework under which they make their institutional and collective choices.

To reap economies of scale and 'netting economies,' banks might find it beneficial to simply spread their reserves among their own branches and headquarters as well as rely on bilateral agreements (Schuler 1992). When transaction costs and economies of scale are external to the firm but internal to the industry, the tendency will be to form institutional structures to collaborate and internalize them (Dowd 1994). However, the institutional decision of how banks will direct those "centripetal forces" to internalize economies of scale and netting economies will widely vary according to the context and constitutional framework determining the number of banks, incentives to collaborate, and availability of economies of scale (Boettke et al. 2007). Possible economies of scale and collective strategies depend on the legal framework they face while attempting to form more complex banking structures. The real institutional heterogeneity seen in banking arrangements resonates with Ostrom's $(2000,2010)$ conception of different patterns of possible organizational and governance structures given the institutional context that binds decision makers' incentives and collaboration possibilities. Only by understanding organizations' decision-making processes in light of a given institutional and legal context can the rationale behind collective outcomes become clear (Ostrom 2010). Ostrom's notion of the contextual patterns of governance structures is equally relevant to understand the different institutional evolutions of banking systems. Hence only through understanding the 'constitutional context' in which banks act, as well as how this affects and limits their incentives to collaborate, is it possible to explain the formation of alternative banking structures. More importantly, this 'Ostromian notion' of banking's diverse 'institutional equilibria' and their different governing structures conditioned by the context severely undermines Goodhart's general account for the natural evolution of just central banks. The constitutional context then constrains the possible individual and collective choices in the emergent institutional "discovery process" of banking, in order for banks to seek economies of scale through different plausible cooperative arrangements.

These insights illuminate theoretically the wider possibilities for the institutional evolution of the centralization of reserves. They show that the formation of the banking system depends on the patterns of collective outcomes in the organization of banking, which is shaped by the regulatory framework that structures collaboration and incentives (Buchanan 2008). Interestingly, these insights imply that Goodhart's rationale for central banking is potentially a polycentric rationale that sustains wider and dissimilar forms of banking structures dependent on the constitutional context that binds self-governing collective action (Brennan and Buchanan 2000/1985; Ostrom 2000). This richer constitutional perspective on 
banking institutions severely weakens Goodhart's narrow evolutionary arguments for the emergence of just central banks. This perspective suggests that an a priori unknown polycentric order of clearinghouses, bankers' banks, or bank-branches network could emerge, conditioned by the 'rules of the game' in which banks could potentially collaborate (Buchanan 2008). In fact, this analysis and the historical evidence strongly suggest that wider possibilities for polycentric private banking arrangements can successfully exist in order to provide-at different levels of governance-the micro functions. Goodhart's (1988) theoretical account for the emergence of a bankers' bank as the sole evolutionary norm of banking draws a narrow and incorrect conclusion since it neglects the constitutional context that constrains governance, collaboration and institutional formation.

\section{Central banking and clearinghouses: an institutional comparison}

As I have shown, Goodhart's claims for the generalized natural formation of bankers' banks and their natural transition to central banks are unwarranted both historically and theoretically; they need to be 'constitutionally contextualized' in order to be coherent. Nevertheless, despite the lack of any historical or theoretical 'natural evolutionary' justification, central banks might still be preferable to clearinghouses in a comparative institutional sense to provide the crucial "micro functions."

Regarding the micro functions, the usual institutional responses for the problems that a banking system faces are similar to institutional responses in other economic activities that suffer informational inadequacy, monitoring and the provision of specialized services. The common institutional response is to establish some form of 'club' or voluntary association. The reason is due to economies of scale and the need to reduce costs to effectively deal with free-rider problems, reputation commons, and informational asymmetries (Yue and Ingram 2012). ${ }^{13}$ Hence, clearinghouses could emerge as 'private clubs' in which non-members are excluded from the key micro-functions services and bank members show direct and constant evidence of their trustworthiness. The club, then, in a way encapsulates information concerning the reputation of the whole club and the responsibility and soundness of its members, informing the market of the accountability of them. The arguments for the existence of this form of club arrangements rests on the fact that the nature of banking leads to the concentration of reserves. In addition, banking activities also possess information asymmetries, potential systemic risks, and reputation and confidence effects that might lead to negative externalities and potential free-rider problems among competing banks (Goodhart 1988; Hardy 2006). At the source of potential bank runs are problems related to conflicts of interest, asymmetries of information, and reputation commons (Goodhart 1988). These problems suggest that the formation of clubs or a central bank could potentially ameliorate them (Yue and Ingram 2012); while evaluating these potential banking problems and

\footnotetext{
13 I am referencing an exclusive club that deals with an impure public good, which is public trust and confidence in the banks (Buchanan 1965).
} 
comparing the institutional properties of how clubs and central banks could handle them, Goodhart favors the latter.

Goodhart's major claim in this institutional comparison leading him to favor central banks rests on his belief that voluntary associations are unable to effectively perform the micro functions. Goodhart maintains that a strong competitive bank member will most likely dominate private clubs and then assume a central administrative role within them, undermining the clubs' performance and impartiality. Goodhart argues that clubs could be ineffective and fail due to greater conflicts of interest, lack of cohesion, bankers' pressure, as well as for-profit incentives that plague clubs; these reasons impose negative externalities on the banking system's regulation and stability (Goodhart 1988, pp. 37-39; 71-73). These deficiencies make clubs unlikely to reliably manage the micro functions in a way that is consistent with public interest (Goodhart 1988, p. 45). Goodhart's preferred solution is for a bankers' bank that dominates clearing arrangements to transition to a full nonprofit governmental status. Nevertheless, just because self-governance possesses challenges and might reveal imperfections, this is not a sufficient condition to claim that a government solution is a priori superior and easily attainable (Demsetz 1969). To avoid falling for the 'nirvana fallacy,' a more thorough comparative institutional analysis is warranted (Demsetz 1969). I undertake this analysis in order to see whether competition among clubs is 'fragile' enough (institutionally speaking) to justify the imposition of an outside agency (Goodhart 1988, p. 4). Although the banking system's natural evolution has not necessarily led to central banks, they might still be preferable to clearinghouses. Thus a comparative institutional analysis is necessary. In order to do so, I evaluate their institutional comparative advantages and weaknesses, based on how they might actually operate under real political conditions and incentives.

To effectively overcome conflicts of interest among members, clubs could appoint an independent body or board of directors. An external firm that provides clearing services, a club council, or a club commission-one that would have no involvement in regular banking businesses - could attain detachment from conflicts of interest natural in banking operations. However, how can such a council be isolated from the pressure of banking members? How can clubs be conducted by organisms insulated from banking pressures while also being able to maintain their independence and accountability? Given these potential conflicts, lack of cohesion, and bank pressures, Goodhart advocates for "the establishment of a public body, which is, however, separated from, and independent of, the immediate political arena" (Goodhart 1988, p. 72). Goodhart's confidence in the possibility of establishing such an institution by political design seems unjustified. While it is true that there are potential conflicts of interest and pressure group problems that critically affect clearinghouses, these issues apply symmetrically to any form of government-established central bank; in fact, it may apply to an even greater degree. The problem is symmetric: how is it that banking supervision and monitoring can be done effectively by public governmental entities insulated from political and private banking pressures?

It has been recognized in the literature that the concentration of power and the increased concentration of supervision of economic activities by a single entity 
largely increases the potential benefits from regulatory capture (Hardy 2006; Laffont and Tirole 1991; Stigler 1971). Bank regulation in its most concentrated forms has been shown to be specifically susceptible to capture by interest groups (Calomiris and Haber 2014; Hardy 2006). These regulatory capture problems present in a single central entity are potentially much more severe than in a system that relies on a decentralized regulatory structure of competing clubs. As Laffont and Tirole (1991) have pointed out, regulatory capture is likely to be increasingly beneficial in economic activities in which interest groups are highly concentrated and there is much at stake. This is especially the case in banking systems lacking high levels of existent or potential competition, with impediments to branching, as well as with a single overall political regulator that concentrates power (Hardy 2006). Commercial banks in a central-bank regulated environment will possess higher collective market shares; this leads to the organization of large banking associations and hence to greater incentives for and potential concentrated gains from regulatory capture (Hardy 2006). The potential gains from capture are therefore larger and the costs much lower in a system in which banks need to capture only a single recognizable supervisory agency. The opposite occurs in systems that have fragmented and competitively shifting responsibility for supervision and regulation distributed among clearinghouses, diluting the potential benefits from capture. ${ }^{14}$

Furthermore, unlike with competitive clubs, it is not only from private banks that a central bank needs to potentially insulate itself, but also from the whole structure of politics, government, interest group pressures, and congressional oversight (Barth et al. 2006; Becker 1983; Kroszner and Strahan 2000; Posner 1974). Public Choice scholars have found these private and political pressures on central banks' capacity to be independent policy makers and effective regulators to be far from negligible. ${ }^{15}$ This suggests that economic pressure from banks, pressure from potential regulatory capture, and political pressure are potentially much bigger and more generalized for central banks. Moreover, if somehow central banks could be potentially isolated from political pressure through providing them political independence, the problem is not resolved but is simply shifted towards how they could be kept accountable and to whom (Cukierman 1994).

Under the establishment of a public body, politically appointed regulators are both protected and disassociated from the potential pecuniary and non-pecuniary costs of a loss of reputation and negligence of the banking club members. This severely lowers their incentives to constantly monitor and guide banks toward socially optimal compliance, exacerbating the possibilities for irresponsible banking behavior (Barth et al. 2006). Regulators, being part of a bureaucracy rather than a competitive collective governance structure, will no longer be part of the reputation commons that usually hold clearinghouses and banks accountable. Hence a

\footnotetext{
${ }^{14}$ Concerns about potential problems with regulatory capture of central banks by big banks seems to be justified given the latest episodes of the Baim Report, the Carmen Segarra recordings, and the case in which the New York Fed was involved with major Wall Street banks in the acquisition of credit default swaps from American International Group (Bernstein 2014; Fox 2014).

15 For a review of presidential and congressional pressures on the Fed, see Meltzer (2009). For a historical review of presidential political pressure on the Fed, see Boettke and Smith (2014).
} 
bureaucracy has a different organizational structure that largely allows it to be detached from the reputation commons of banks and their behavior. This alters the regulators' incentives structure, their cost-benefit analysis and their optimal decision making in regards to regulation. More importantly, this potentially allows for the possibility that regulators might pursue their narrow self-interests rather than 'socially optimal' levels of supervision and regulation (Boot and Thakor 1993). This structure further intensifies wider potential pressure from politicians, internal bureaucratic disputes, and interest groups' pressures to use and leverage bank regulation for redistribution and other populist ends (Becker 1983; Barth et al. 2006). Overall, the bureaucratic arrangement generates a misalignment of incentives under the public structure in which regulators first externalize the costs of banks' negligent risk management and loss of reputation then internalize the benefits of potential regulatory capture. These misaligned incentives bring potential repercussions in the long run for the stability of the entire banking system. The economic theory of regulation provides reasons to be highly skeptical about how central banks can optimally deal with the "micro functions" (Posner 1974; Stigler 1971). In contrast, the potential overall benefits from competitive private regulation might be larger since such institutions are driven mainly by profit, competition and banking efficiency, rather than by rent seeking and political objectives (Calomiris and Kahn 1996).

Clearinghouses' emergent regulations and standards are largely motivated by the self-interest of the members involved (Dowd 1994). The costs of a loss of reputation of the clearinghouse and/or the banks are entirely internalized by the members and the clearinghouse (Yue and Ingram 2012). Additionally, if a bank member seeks to capture the club for its own benefits, in the long run it will only undermine the club itself, possibly leading it to collapse. Hence, the cost of capture is internalized to all the members, making such cost in the long run higher than the possible short-term benefits. Furthermore, since commercial banks suffer from stochastic fluctuations of their reserves, they will potentially rely on the interbank lending of the club. It is in their best interest to keep the clearinghouse afloat, defend its integrity, and to constantly inform it of their solvency and activities; this further aligns banks' incentives toward compliance and to allow others to monitor them. Competition and decentralization create the conditions by which the independent body of the clearinghouse will have the incentives to uphold appropriate rules and apply them equally to the members. Consequently, its objectives are to obtain profit by providing a long-term valuable service and to avoid bank members' exit or a degradation of the quality of the regulation and supervision. Similarly, bank members also have incentives to collaborate and disclose information (Dowd 1994).

Under these competitive arrangements, the reputation commons and the collective benefits lead banks to willingly adjust their profit-maximization strategies to private regulation. This adjustment is based on the banks' costs of noncompliance with the clearing rules and hence the risk of losing their membership and benefits. Since banks find it economically (and risk-wise) beneficial to be part of the club to access an interbank lending market and to reduce their reputation problems, this further incentivizes them to adjust their profit-maximizing strategies to the club's rules. A decentralized order of clubs reduces moral hazard and the 
potential tensions between profit-maximizing behavior, the optimal amount of reserves, and negative externalities from imprudent banking (Calomiris and Kahn 1996).

\subsection{Decentralized regulation and supervision}

Despite the aforementioned, according to Goodhart the capacity of banks to achieve a higher and stable degree of self-governance is questionable. He argues that the degree to which self-regulation can operate by independent agencies will critically depend on the cohesion of the bank members, the actual number of members, and the complexity and heterogeneity of their activities (Goodhart 1988, pp. 72, 103). Goodhart seems to attribute a large number of members and a lack of cohesion among them as the reasons why "clubs' associations" will not be able to maintain self-regulation properly. His theoretical mistrust of clearinghouses is based on the assumption that a private regulatory "service" cannot be provided consistently due to large increases in membership, irreducible conflicts of interests among members, or heterogeneity, which leads to a lack of cohesion and club instability (Goodhart 1988, pp. 71-73). Contrary to Goodhart, Hardy (2006) shows that when there is only a single entity regulating the banking system, it increases the benefits for big banks to encourage stricter regulation rather than 'socially optimal' rules. Hardy also shows that when regulatory jurisdictions compete, the regulatory regimes do not need to converge to a homogenous set of regulations. Nor competition will lead to a convergence toward low levels of regulation or a "race to the bottom" regulatory equilibrium (Hardy 2006). ${ }^{16}$ In fact, competitive clearinghouses may not always seek to weaken their regulatory regime, even if they act in the interest of their bank members. Instead, a clearinghouse or “jurisdiction's competitive strategy needs to weight the direct cost of tough regulation against the higher financing cost provoked by a reputation of lax prudential rules and supervision. Moreover, jurisdictions may become highly differentiated" (Hardy 2006, p. 19, emphasis added).

The fundamental implication of Hardy's analysis is that the institutional and regulatory characteristics of a given clearinghouse are self-reinforcing, heterogeneous and do not need to converge. Additionally, the clearinghouses' selfreinforcing characteristics and differentiations allow a polycentric institutional order to form, under which each clearinghouse distinguishes itself by providing a unique regulatory and monitoring bundle of "micro functions" or services. Hence under competition they will differentiate in a banking process of Tiebout sorting (Rosen 2003; Tiebout 1956). ${ }^{17}$ This sorting leads to more personalized services and regulation of the bank members, allowing the formulation of alternative sets of rules that are better aligned with the members' actual and ever-changing banking activities and needs. Competitive regulation profits from banks' local preferences and contextual procedural knowledge, increasing regulatory efficiency and financial

\footnotetext{
${ }^{16}$ For empirical evidence of the positive properties of competition among bank regulators, see Rosen (2003).

17 See also Rosen (2003). One of the advantages of Tiebout sorting is that it occurs within a private competitive-governance context and therefore avoids problems associated with quasi-market failures.
} 
stability (Hardy 2006; Rosen 2003; Yue and Ingram 2012). The emergent rules in this competitive setting reflect local banks' needs and business methods, promoting a constant "regulatory discovery process" on behalf of clearinghouses. This also enables strong economic and epistemic feedback mechanisms between banks and regulators. These mechanisms would be swifter and stronger than those available through political processes (Boettke et al. 2007). When banks as customers are involved in the self-reinforcing process of establishing clubs' regulations and procedures, they will willingly communicate their common practices and preferences to clubs. The regulations and monitoring processes of the members can be done with more specialized knowledge and therefore more efficiently. On the other hand, regulations that come from a top-down noncompetitive context can potentially respond to other sets of extra-market incentives and political pressures. Top-down regulation could respond to inferior, and contextually different, regulatory feedbacks for learning and improving policy (Becker 1983; Boettke et al. 2007). Central banking regulation can then be severely disassociated from the banking context, their real business activities and can even respond to interest groups and ideology (Barth et al. 2006; Kroszner and Strahan 2000; Posner 1974). This potentially redirect the 'optimal set of rules' and monitoring away from what banks actually need and demand, toward what interest groups and politicians need and demand.

A crucial aspect of the self-reinforcing regulatory element of clearinghouses is that it actually leads to a sorting and concentration of homogenous banks that seek a similar set of regulation, and other banking services (Hardy 2006; Tiebout 1956). This concentration allows the market for banking clearing and regulation to fragment into a decentralized polycentric structure of different sizes, as well as different forms of cohesion and regulation. Additionally, contrary to Goodhart's misgivings, system-wide sorting actually increases local homogenization, coordination and cohesion among the bank members by decreasing unnecessary growth of bank membership and potential conflicts of interest among them (Calomiris and Kahn 1996; Tiebout 1956). Since banks actually benefit from lower rates, more liquid interbank lending and a reputation commons, they have the incentive to not impose (unreasonable) barriers to entry to new potential members. ${ }^{18}$ These aforementioned characteristics increase the possibility of a stable competitive set of regulatory "services" across the system of clearinghouses, avoiding cohesion problems and conflicts of interest. These stability properties are actually nonexistent in a top-down centralized regulatory system that curtails competition and the decentralized "discovery process of rules."

The conclusion of the analysis of competitive regulations is that the concentration of regulatory roles into a single bureaucratic entity cannot be justified comparatively. Competitive self-governing regulatory institutions seem to be far stronger and superior than what Goodhart assumes. These findings are further supported by historical evidence with application to clearinghouses (Yue et al.

\footnotetext{
18 The greater stability of private arrangements has been shown by available data (Yue and Ingram 2012).
} 
2009). ${ }^{19}$ All this shows that Goodhart's reservations regarding the degrees of efficiency and 'institutional robustness' of bankers' clubs in dealing with conflicts of interest and member pressures seem far less justified. Furthermore, his confidence in a single "politically isolated" entity is far more unsubstantiated than previously acknowledged.

\section{Conclusions}

The post-crisis literature has not paid much attention to the "micro functions" that could justify central banks. It has neither drawn attention to the core arguments that sustain an institutional justification nor the evolution of central banks. I hope that this paper has contributed to research in this direction. Since Goodhart's (1988) thesis rests on the fact that the "micro functions" are the core justification for central banks, I provided historical and institutional evidence to scrutinize and question the rationale sustaining his thesis. I have extended the arguments on banking institutions by finding a bridge between them and the theory of clubs and self-governance which could be a fruitful path for further research. In regards to Goodhart's claims, I reviewed evidence that disputes Goodhart's generalized historical claims. Furthermore, I showed that his institutional rationale for central banking is not inescapably a narrow rationale exclusively for it, but rather a rationale for a wider possible set of alternative polycentric arrangements able to provide crucial banking services. I have also suggested that the possible emergence of clearinghouse 'polycentricity' and branch-banking networks are severely conditioned to the 'constitutional context' and the legal framework that banks face.

These arguments have deep implications. First, central banks are not a natural, inherent phenomenon but rather the outcome of an evolution — dependent on a skewed institutional framework that suppresses competition and granted monopoly powers. Thus societies do not carry the burden of being institutionally "trapped" with central banks. They can and they should look for more resilient alternatives based on rearrangements of property rights and legal frameworks (Selgin 1988, chapter 11). Second, by showing how competitive private clubs may better provide the "micro functions," I have hinted that lending on distress, financial regulation and prevention of bank runs are not entirely 'public goods' but rather they possess deep characteristics of 'privateness'. Hence their successful provision resides more within the realm of private competitive clubs than in the system of pure public goods (Buchanan 1965). This has repercussions for banking policy and financial stability since it opens the possibilities of seeking banking reforms based on private governance and polycentric banking. These previously unrecognized institutional arrangements are plausible and robust solutions to banking regulation and macroeconomic stability.

On comparative institutional grounds, there are no strong reasons to favor the formation of central banks to the formation of clearinghouses in order to deal with

\footnotetext{
${ }^{19}$ Yue and Ingram (2012) review the episode of the New York Clearing House Association. They show that the self-governance of clubs can be quite a successful strategy for the members to deal with interbank lending, promote collective solvency, and prudent lending among them.
} 
the micro functions. I showed that given the nature of banking, the generalized arguments for the natural evolution of the banking system toward a central bank is groundless. Instead, the rationale and need for the micro functions is a justification for the emergence of different institutional arrangements that might vary widely according to the context that banks face. Given the constitutional framework binding collective action, different forms of arrangements might emerge from the full decentralization of banks toward more hierarchical structures. To what extent the banking system moves toward one end or the other depends on the market context, and the legal framework that banks face in order to collaborate.

In sum, there is no generalized justification for central banking such as Goodhart claims. When evaluating the comparative properties of arrangements, I showed that clearinghouses seem to deal much better with the "micro functions" than central banks. Self-governance is better at dealing with incentive misalignments, regulatory capture, and political pressure. On comparative grounds, I find that the institutional preference for central banks over a polycentric system is erroneous. I conclude that both history and theory show that the natural justification for central banks is unfounded. Hence Goodhart's attempt to provide a general justification for central banks is mistaken and their comparative defense, much weaker than previously acknowledged.

Acknowledgments I am grateful to Alexander Salter, Charles Goodhart, Kevin Dowd and two anonymous referees for constructive comments. I thank Harry David and Victoria Finn for editing assistance.

Open Access This article is distributed under the terms of the Creative Commons Attribution 4.0 International License (http://creativecommons.org/licenses/by/4.0/), which permits unrestricted use, distribution, and reproduction in any medium, provided you give appropriate credit to the original author(s) and the source, provide a link to the Creative Commons license, and indicate if changes were made.

\section{References}

Bagehot, W. (1873). Lombard street: A description of the money market. London: Henry S. King.

Barth, J. R., Caprio, G., \& Levine, R. (2006). Rethinking bank regulation: Till Angels Govern. New York: Cambridge University Press.

Becker, G. (1983). A theory of competition among pressure groups for political influence. Quarterly Journal of Economics, 98, 371-400.

Bernstein, J. (2014). Inside the New York Fed: Secret recordings and a culture clash. ProPublica.org. http://www.propublica.org/article/carmen-segarras-secret-recordings-from-inside-new-york-fed.

Boettke, P. J., Coyne, C. J., \& Leeson, P. T. (2007). Saving government failure theory from itself: Recasting political economy from an Austrian perspective. Constitutional Political Economy, 18, 127-143.

Boettke, P. J., \& Smith, D. J. (2014). Federal reserve independence: A centennial review. Journal of Prices and Markets, 1(1), 31-48.

Boot, A. W., \& Thakor, A. V. (1993). Self-interested bank regulator. The American Economic Review, 83(2), 206-212.

Brennan, G., \& Buchanan, J. (2000/1985). The reason of rules: Constitutional political economy (Collected Works of James Buchanan, Vol. 10). Indianapolis: Liberty Fund. 
Broz, J. L. (1998). The origins of central banking: Solutions to the free-rider problem. International Organization, 52, 231-268.

Buchanan, J. (1964). What should economists do? Southern Economic Journal, 30(3), 213-222.

Buchanan, J. (1965). An economic theory of clubs. Economica, 32(125), 1-14.

Buchanan, J. (2008). Same players, different game: How better rules make better politics. Constitutional Political Economy, 19, 171-179.

Calomiris, C. W., \& Haber, S. H. (2014). Fragile by design: The political origins of banking crises and scarce credit. Princeton, NJ: Princeton University Press.

Calomiris, C. W., \& Kahn, C. M. (1996). The efficiency of self-regulated payments systems: Learning from the Suffolk System. Journal of Money, Credit, and Banking, 28, 766-797.

Clay, H. (1957). Lord norman. London: Macmillan \& Co., Ltd.

Cukierman, A. (1994). Central bank independence and monetary control. Economic Journal, 104, $437-448$.

Demsetz, H. (1969). Information and efficiency: Another viewpoint. Journal of Law and Economics, 12(1), 1-22.

Dowd, K. (1992). The experience of free banking. London: Routledge.

Dowd, K. (1993). Laissez-faire banking. London: Routledge.

Dowd, K. (1994). Competitive banking, banker's clubs, and bank regulation. Journal of Money, Credit and Banking, 26(2), 289-308.

Einzig, P. (1932). Montagu norman: A study in financial statesmanship. London: Kegan Paul, Trench, Trubner \& Co., Ltd.

Fox, J. (2014). Why the fed is so wimpy Harvard business review article. https://hbr.org/2014/09/whythe-fed-is-so-wimpy/.

Glasner, D. (1989). Free banking and monetary reform. Cambridge, MA: Cambridge University Press.

Goodhart, C. (1988). The evolution of central banks. Cambridge, MA: MIT University Press.

Goodhart, C. (2010). The changing role of central banks, BIS working papers no 326, November 2010.

Hardy, D. C. (2006). Regulatory capture in banking, IMF working paper, WP/06/34.

Hetzel, R. L. (2012). The great recession: Market failure or policy failure?. Cambridge: Cambridge University Press.

Jácome, L. (2015). Central banking in Latin America: From the gold standard to the golden years. IMF working paper no. $15 / 60$.

Kroszner, R. S., \& Strahan P. E. (2000). Obstacles to optimal policy: The interplay of political and economics in shaping bank supervision and regulation reforms, NBER working paper no. 7582.

Laffont, J., \& Tirole, J. (1991). The politics of government decision-making: A theory of regulatory capture. Quarterly Journal of Economics, 106(4), 1089-1127.

Lake, W. S. (1947). The end of the Suffolk System. Journal of Economic History, 7, 182-207.

Marcussen, M. (2005). Central banks on the move. Journal of European Public Policy, 12(5), 903-923.

Meltzer, A. H. (2009). A history of the federal reserve (Vol. 2). Chicago: University of Chicago Press.

Ostrom, E. (2000). Collective action and the evolution of social norms. Journal of Economic Perspectives, 14(3), 137-158.

Ostrom, E. (2010). Beyond markets and states: Polycentric governance of complex economic systems. American Economic Review, 39(1), 7-27.

Posner, R. A. (1974). Theories of economic regulation. Bell Journal of Economics and Management Science, 5, 335-358.

Rosen, R. J. (2003). Is three a crowd? Competition among regulators in banking. Journal of Money, Credit, and Banking, 35(6), 967-998.

Sayers, R. S. (1976). The bank of England 1891-1944. (Official history of the bank of England). Cambridge: Cambridge University Press.

Schuler, K. (1992). The world history of free banking: An overview. In K. Dowd (Ed.), The experience of free banking (pp. 7-47). London: Routledge.

Selgin, G. (1988). The theory of free banking: Money supply under competitive note issue. Totowa, NJ: Rowman and Littlefield.

Selgin, G. (1993). The rationalization of central banks. Critical Review, 7(2-3), 335-354.

Selgin, G., \& White, L. H. (1999). A Fiscal theory of government's role in money. Economic Inquiry, 3(1), 154-165.

Singleton, J. (2011). Central banking in the twentieth century. Cambridge: Cambridge University Press.

Smith, V. (1990/1936). The rationale of central Banking and the free banking alternative. Indianapolis: Liberty Fund. 
Stigler, G. (1971). The economic theory of regulation. Bell Journal of Economics, 2, 3-21.

Thornton, H. (1978/1802). In F. A. Hayek (Ed.), An enquiry into the nature and effects of the paper credit of Great Britain. Fairfield, NJ: A. M. Kelley.

Tiebout, C. M. (1956). A pure theory of local expenditures. Journal of Political Economy, 64(5), 416-424.

Timberlake, R. H., Jr. (1984). The central banking role of clearinghouse associations. Journal of Money, Credit, and Banking, 16(1), 1-16.

Trivoli, G. (1979). The Suffolk bank: A study of a free-enterprise clearing system. London: The Adam Smith Institute.

White, L. H. (1984). Free banking in Britain; Theory, experience, and debate, 1800-1845. Cambridge: Cambridge University Press.

Yue, L., \& Ingram, P. (2012). Industry self-regulation as a solution to the reputation commons problem: The case of the New York clearing house association. In T. G. Pollock \& M. L. Barnett (Eds.), The Oxford handbook of corporate reputation. Oxford: Oxford University Press.

Yue, L., Luo, J., \& Ingram, P. (2009). The strength of a weak Institution: Clearing house, federal reserve, and Manhattan banks. In Best paper proceedings of the academy of management meeting. Chicago. 